\title{
Development by Apply Problem Based Learning Models to Increase Students Creativity of State Vocational High School 1 Cerme
}

\author{
Asti Satriawati ${ }^{12 *}$, Luthfiyah Nurlaela ${ }^{1, b}$, Munoto ${ }^{1,}$, and Tri Rijanto ${ }^{1, d}$ \\ 1Department of Technology and Vocational Education, Postgraduate, State University of Surabaya, Surabaya, 60231, \\ Indonesia \\ a astis.pd16070895010@mhs.unesa.ac.id; b nurlaela@unesa.ac.id; c munoto@unesa.ac.id; d rijanto@unesa.ac.id \\ *Corresponding Author: astis.pd16070895010@mhs.unesa.ac.id | Phone : +62823-3420-4110
}

Received: 23 July 2020

Revised: 27 August 2020

Accepted: 4 September 2020

\begin{abstract}
This study is a research on the development of devices in basic culinary subjects by applying a problem based learning models to increase students' creativity, consisting of: 1) analysis the validity of the device, 2) analysis the practicality of the device, and 3) analysis the effectiveness of the device. This research was conducted in three stages of the 4-D model, which are defined, design, and develop. A device that have been developed will be tested in 10th Culinary Art 1 and 10th Culinary Art 2 grade of state vocational high school 1 Cerme in even semester of academic year 2019/2020 with by using a research design of One Group Pre-test Post-test Design Learning tools developed include: syllabus, lesson plans scenario, student book, worksheet and key worksheet, affective (social skills), affective (character behavior), cognitive (product), cognitive (process), cognitive (scientific creativity), and psikomotor. The results showed that (a) learning tools that are developed are valid, (b) the learning process runs well, (c) student creativity learning outcomes produce an increase in the high category.
\end{abstract}

Keywords: Creativity; Culinary Art; Device Development;

\section{Introduction}

Education is one of the dynamic world developed by humans who are dynamic in the future. Therefore the development of education is something that has been done by the next generation to support the improvement of education in a region or country. Changes in the education system are conscious and planned efforts to realize learning and learning processes so that students can actively develop the potential associated with spiritual, religious, intelligence, and skills needed, society, nation, and country (Indiantoro \& Vivid, 2017).

Basic food is one of the productive subjects that must be taken by students in the department of catering. The concept of basic culinary subjects is a branch of science in the culinary field that discusses the basic theory of cooking in order to be applied in the industrial world or everyday life. The thing that happened at of state vocational high school 1 Cerme was the lack creativity of students in sambal competence. In conveying the chili material needed a more special way because the material taught is related to various kinds of Indonesian chili sauce. Therefore, we need a lesson plan that can increase creativity and learning outcomes. In this case, it is in line with the 2017 Minister of Education Regulation on syllabus examples and 2016 revised lesson plans scenario on the third (cognitive) core competency that reads understanding, knowledge based on curiosity about creative thinking.

According to Torrance (Hebert, Cramond, Neumeister, Millar, \& Silvian, 2002) the ability to think creatively is the attitudes and behaviors of students included in cognitive skills (scientific creativity) that reflect the following indicators: 1) fluent thinking; 2) flexible thinking; 3) original thinking; and 4) elaboration thinking. Creative thinking or high-level thinking requires educators 'conscious effort to develop students' creative potential. Therefore, to create creative students is the duty of the teacher.

Law Number 20 of 2003 in article 3 states that the purpose of national education is to develop the potential of students to be creative according to their skills. On the other hand, Law Number 14 Year 2005 concerning Teachers and Lecturers states that teachers are professional educators with the main task of educating, teaching, guiding, directing, training, evaluating, and evaluating students at the secondary education level. Therefore, the main task of the teacher is to develop the potential of students by teaching, 
guiding, directing, training, assessing and evaluating to become a creative person.

Based on the results of the interview (2019), that of state vocational high school 1 Cerme teachers have used the 2013 curriculum for the 2016/2017 school year until now the teacher is still using the learning tools provided by the school. The teacher of basic culinary in the learning process provides students with the material to memorize concepts and not to use concepts if they encounter problems in real life related to the concepts they have. Learners have not been able to find problems and formulate these problems. The problem now is how to find a way so that students can apply and remember longer concepts and connect with the real world? How good teachers are able to develop learning tools and determine the right learning model to solve current problems.

Teachers are required to be able to plan learning tools before learning is carried out in class. Learner design (Law Regulation of The Minister of Education and Culture Number 22 year 2016), consisting of: syllabus, lesson plans, textbooks and assessment sheets. A special learning tool is needed to increase student creativity. Therefore it is necessary to develop learning tools that can enhance creativity, including: syllabus, lesson plans scenarios, worksheets and key worksheets, student books, affective assessment (social skills), affective assessment (character behavior), cognitive assessment (products), cognitive assessment (process), cognitive assessment (scientific creativity), and psychomotor assessment. The purpose of this study is to provide convenience and improve the competence of students as knowledge of students, as stock and experience. Learners become more competent in solving problems than in concept or practice.

Teacher competencies explained in the Minister of National Education Regulation Number 16 Year 2007 are developed as a whole in four main competencies, namely: a) pedagogical competencies; b) personality competence; c) social competence; and d) professional competence. This can be done if the main competencies are achieved through making learning tools that can improve learning outcomes, especially student creativity.

Students are prepared to face a challenging future, can solve everyday problems, prepare to compete and create new opportunities, and play a role in scientific innovation and technological development in the digital age (Suyidno, 2017). The teacher can adjust which learning model can help the success of the teaching and learning process and increase student creativity. The teacher and all students can play an active role in ongoing learning to get maximum results. One step in determining the learning model that allows to be developed to stimulate creative thinking skills (connections, questions, observations, and experiments) in solving problems is Problem Based Learning (PBL). Increase explicit creativity in PBL objectives, namely: a) guided inquiry skills and problem solving; behave like an adult; and the ability to study independently (Nur, 2011). Based on the reality at SMK Negeri 1 Cerme, the job sheet that is used has not used scientific and cognitive methods yet has not taught indicators of creative thinking skills. The aspects of scientific creativity are described in the scientific structure creative model as a measurement tool used to measure creativity in reference to the scientific structure creative model developed by Hu \& Adey (2002). Therefore, aspects of scientific creativity are considered most appropriate using problem based learning models.

Regulation of the Minister of Education and Culture of the Republic of Indonesia Number 23 Year 2016 article 1 regarding education assessment standards explains that the criteria in the scope, goals, benefits, principles, mechanisms, procedures, and instruments of assessment of student learning outcomes tests are selected as guidelines in the assessment of participant learning outcomes tests students in primary and secondary education. The 2013 Revised Curriculum in 2016 focuses on connecting or linking core competencies and basic competencies. Improvements or Revisions to the 2013 Curriculum in 2016 are, (1) integrating Strengthening Character Education; (2) integrating literacy, the School Literacy Movement; (3) 21st century skills or termed 4C (Creative, Critical Thinking, Communicative, and Collaborative). In an effort to update the lesson plans scenario tool that can support teachers in providing lessons to improve the ability of creativity in students (Zubaidah, 2016); and (4) integrating HOTS (High Order Thinking Skill). The aim is to achieve cognitive skills in solving problems logically, structured, and responsibles.

Problem Based Learning is applying it to create and stimulate higher-order thinking skills in all problem-oriented orientation situations, including learning how to learn. The characteristics of the learning model based on the problem, is asking a number of questions or problems; focus on interdiscipline; authentic inquiry; creating a real work and showing it a work; and collaborating (Nur, 2011). The problem based learning model is a constructivist pedagogy in which students learn science and develop critical thinking skills by solving real world problems in small groups. The results of the study have shown that PBL students are more motivated and become better students Preetha, Aswhin, \& Chris (2005). The efforts made by the teacher to stimulate ideas, develop ideas and solve problems are seen in the activities of students in asking questions, discussing, expressing opinions both in groups and between groups.

Visual representations of vocational education and skills revitalization programs implemented by pilot vocational schools include planning and implementing curricula with the business world and the industrial world; innovating learning with the professionalism of teachers and educators; standardization of the most 
important facilities and infrastructure; updated industrial cooperation system; manage and organize an institution; and increasing certification access to expertise competencies (Ministry of Education and Culture 2017 concerning Examples of 2017 Syllabus and Revised Lesson Plans Scenarios). Students must understand scientific creativity in an effort to realize the golden generation of Indonesia in 2045 (Suyidno, 2015). This is in line with the government's plan to plan and implement of the the business world and the industrial world, so learning tools are needed to support the potential of students to compete in the global era.

\section{Methods}

This study aims to develop learning tools that can then be carried out in class so that this research is categorized as research and development in the field of education using R \& D by Borg and Gall (1983: 772).

The design of the learning device trial goes through three stages, namely expert validation, small group test and field test. Expert validation was carried out by 2 competent validators, one of whom were experts in the field of education and one other expert in the field of material. The small group test was conducted limited to 12 students of class 10th Culinary Art of state vocational high school 1 Cerme and the field test was carried out using a large class containing 69 students of class 10th Culinary Art of state vocational high school 1 Cerme can be see in Table 1.

Table 1. R \& D Design

\begin{tabular}{lcc}
\hline & Trial I & Trial II \\
\hline Group I & $\mathrm{O}_{1} \mathrm{X}_{1} \mathrm{O}_{2}$ & $\mathrm{O}_{3} \mathrm{X}_{1} \mathrm{O}_{4}$ \\
\hline
\end{tabular}

\section{Description:}

Group I: group class for trial I

Group II: group class for trial II

O1: pre-test to obtain the results of the creativity process of the sambal material, before the initial meeting (first meeting) Group I.

O2: post-test to obtain the results of the creativity process of the sambal material, at the final meeting (sixth meeting) Group I

O3: pre-test to obtain the results of the creativity process of the sambal material, before the initial meeting (first meeting) Group II

O4: post-test to obtain the results of the creativity process of the sambal material, at the final meeting (sixth meeting) Group II.

X: learning carried out by researchers by applying sambal material learning tools to enhance the creativity of Group I and Group II.

\section{Results and Discussions}

\subsection{Expert Validation}

Expert validation was carried out by two validators. The assessment is focused on aspects of content, appearance and format. The validation results are presented in Table 2.

Table 2. Validation Results

\begin{tabular}{lcc}
\hline \multicolumn{1}{c}{ Assessment Aspects } & Average (\%) & Criteria \\
\hline Implementation of the learning & $93,33 \%$ & Very Good \\
Readability of student books & $86,5 \%$ & Very Good \\
Readability of worksheet & $75,83 \%$ & Very Good \\
Cognitif (product) & 9 students & Complete \\
Cognitif (process) & 12 students & Complete \\
Cognitif (scientific creativity) & & \\
a. Average & $82,04 \%$ & Complate \\
b. Individual completeness & 7 students & Complete \\
c. Item sensitivity index & 0,4 & sensitive \\
\hline Psikomotor & $82 \%$ & Very Good \\
\hline
\end{tabular}

Based on the table 2, showed that validation results with a high category so that the learning tool can be said to be feasible with a little revision.

\subsection{Limited Trial}

Limited trial use revised learning tools based on input from the validator and are tested on a 12 of students. Small group test results are presented in Table 3.

Table 3. Limited Trial 
From the results of the table above explained that the learning tools used in limited trials have quite good results.

\subsection{Field Trial}

Field trials using learning tools were revised based on input and tested on 69 students. The results of the field trial tests are presented in Table 3.

\begin{tabular}{|c|c|c|}
\hline Learning Media & Average (\%) (\%) & Criteria \\
\hline Syllabus & $97,95 \%$ & Very Valid \\
\hline Lesson plan scenario & $95,15 \%$ & Very Valid \\
\hline Students book & $98,72 \%$ & Very Valid \\
\hline Worksheet & $97,82 \%$ & Very Valid \\
\hline Affective (social skills) & $91,89 \%$ & Very Valid \\
\hline Affective (character behavior) & $94,31 \%$ & Very Valid \\
\hline Cognitif (product) & $92,99 \%$ & Very Valid \\
\hline Cognitif (process) & $83,82 \%$ & Very Valid \\
\hline Cognitif (scientific creativity) & $91,08 \%$ & Very Valid \\
\hline Psikomotor & $97,82 \%$ & Very Valid \\
\hline
\end{tabular}

\begin{tabular}{|c|c|c|}
\hline Assessment Aspects & Average (\%) & Criteria \\
\hline Implementation of the learning plan & $97,82 \%$ & Very Good \\
\hline Readability of student books & $92,47 \%$ & Very Good \\
\hline Readability of worksheet & $84,09 \%$ & Very Good \\
\hline Affective (social skills) & $82,50 \%$ & Very Good \\
\hline Affective (character behavior) & $80,35 \%$ & Very Good \\
\hline Cognitif (product) & 66 students & Complete \\
\hline Cognitif (process) & 66 students & Complate \\
\hline \multicolumn{3}{|l|}{ Cognitif (scientific creativity) } \\
\hline a. Average & $91,02 \%$ & Very Good \\
\hline b. Individual completeness & 59 students & Complate \\
\hline c. Item sensitivity index analysis & 0,4 & sensitive \\
\hline Psikomotor & $90,63 \%$ & Very Good \\
\hline
\end{tabular}

\section{Concluions}

The conclusion of this study is that the learning tools that have been developed are classified as valid, practical and effective, with details, namely: (1) It is said to be valid and feasible to use because the results of expert validation show all learning devices are classified as very valid criteria. (2) It is said to be practical to use because the results of the implementation of lesson plans scenario are classified as very good and (3) It is said to be effective to support learning activities, because cognitive learning outcomes (scientific creativity) have reached individual completeness and sensitive items, the results of learning processes and students' psychomotor are classified as very well.

\section{References}

Borg, W. R., \& Gall, M. D. (1989). Educational research: an introduction (4th Ed.). New York: Longman.

Nur, Mohamad. (2011). Problem Based Learning (2nd Ed., 3rd mold). School of Science and Mathematics Center, Ministry of National Education Surabaya. State University of Surabaya.

Hebert, T. P., Cramond, B., Neumeister, K. L. S., Millar, G. \& Silvian, A. F. (2002). E. Paul Torrance: His Life, Accomplishments, and Legacy, 1-59. https://eric.ed.gov/?id=ED505439

Hu, W., \& Adey, P. (2002). A Scientific Creativity Test For Secondary School Students. International Journal of Science Education, 24(4), 389-403. https://www.scirp.org/(S(lz5mqp453edsnp55rrgjct55))/reference/ReferencesPapers.aspx?ReferenceI $\mathrm{D}=1505034$

Indiantoro, A., \& Vivid, W. (2017). Justitia Changes to Higher Education Policy System in Law Education Dimensions. Jurnal Hukum. 1(2), 267-278. https://www.researchgate.net/publication/323009085_Perubahan_Sistem_Kebijakan_Pendidikan_Ti 
nggi_Dalam_Dimensi_Pendidikan_Hukum

Preetha, R., Aswhin, R., \& Chris, S. (2005). From Student Learner To Professional Learner: Training For Lifelong Learning Through On-Line PBL. Case Book is under development and is copyrighted by Emory University and Georgia Institute of Technology, 1-10. https://ashwinram.org/2005/06/09/

Suyidno. (2015). Pemahaman Kreativitas Ilmiah Mahasiswa Dalam Pembelajaran Kreatif Pada Mata Kuliah Fisika Dasar. Proseding Seminar Nasional Pendidikan Sains Tahun 2015, 1361-1366. https://www.researchgate.net/publication/313309741_Pemahaman_Kreativitas_Ilmiah_Mahasiswa_ dalam_Pembelajaran_Kreatif_pada_Mata_Kuliah_Fisika_Dasar

Zubaidah, S. (2016). 21st Century Skills: Skills Taught Through Learning. Proseding Seminar Nasional Pendidikan, 1-18.

Law 2017 Minister of Education Regulation on syllabus examples and 2016 revised lesson plans scenario. http://vervalsp.data.kemdikbud.go.id/prosespembelajaran/file/Permendikbud_Tahun2016_Nomor 022_Lampiran.pdf

Law Number 20 of 2003 in article 3 states that the purpose of national education. http://luk.staff.ugm.ac.id/atur/UU20-2003Sisdiknas.pdf

Law Regulation Of The Minister Of Education And Culture Number 22 year 2016. https://bsnpindonesia.org/wp-content/uploads/2009/06/Permendikbud_Tahun2016_Nomor022_Lampiran.pdf

Law Regulation of the Minister of National Education of the Republic of Indonesia Number 16 Year 2007 concerning Teacher Competencies. http://vervalsp.data.kemdikbud.go.id/prosespembelajaran/file/Permendiknas $\% 20$ No\%2016\%20Tah un\%202007.pdf

Law Regulation of the Minister of Education and Culture of the Republic of Indonesia Number 23 Year 2016 article 1 concerning Education Assessment Standards. https://bsnp-indonesia.org/wpcontent/uploads/2009/09/Permendikbud_Tahun2016_Nomor023.pdf

Law Ministry of Education and Culture 2017 concerning Examples of 2017 Syllabus and Revised RPP Scenarios.

http://vervalsp.data.kemdikbud.go.id/prosespembelajaran/file/Permendikbud_Tahun2016_Nomor 022_Lampiran.pdf 